\title{
Security and military balance in the Black Sea region
}

\section{Özgür Özdamar}

To cite this article: Özgür Özdamar (2010) Security and military balance in the Black Sea region, Southeast European and Black Sea Studies, 10:3, 341-359, DOI: 10.1080/14683857.2010.503643

To link to this article: http://dx.doi.org/10.1080/14683857.2010.503643

册 Published online: 22 Sep 2010.

Submit your article to this journal $[\pi$

Џll Article views: 363

Q View related articles $\square$

Citing articles: 1 View citing articles ๘ 


\title{
Security and military balance in the Black Sea region
}

\author{
Özgür Özdamar* \\ Department of International Relations, Bilkent University, Ankara, Turkey
}

(Received 7 January 2010; final version received 26 July 2010)

\begin{abstract}
This paper analyses the current security challenges and military balance in the Black Sea region. The region, which has been going through vast political and economic transformations since the end of the Cold War, has become a platform for great power rivalry in the last few years. NATO expansion and Russian resistance to it, combined with the existing protracted conflicts, resulted in the first major regional war in a decade. The Russia-Georgia war of 2008 proved that regional actors still perceive the use of force as an acceptable tool of foreign policy. The changing military balance and abrupt increases in military expenditure from some actors suggest that the likelihood of other interstate conflicts in the region is high. Providing security and stability in the Black Sea seems more difficult than the pre-August 2008 war period.
\end{abstract}

Keywords: Black Sea; European Union; military balance; NATO; Russia; security; Turkey; United States

\section{Introduction}

The Black Sea region is at the forefront of the global strategic agenda in the first decade of the twenty-first century, especially after the growing Euro-Atlantic interest in the region followed by the Russia-Georgia war in August 2008. The region has undergone political, social and economical transitions simultaneously since the end of the Cold War. The rapid political developments that took place in the eastern and western shores of the basin require new approaches and patterns to analyse the new security context in the region. Romania's and Bulgaria's NATO and European Union (EU) memberships, Turkey's start of accession talks with the EU, the coloured revolutions in Ukraine and Georgia and these countries' bid for NATO membership, Russia's new assertive foreign policy and the Russia-Georgia war over South Ossetia are some indicators of the Euro-Atlantic inclinations and Russia's reactions against such an integration into western institutions.

Paradoxically, the Cold War provided some degree of stability and security to the Black Sea region. Contrary to the other 'fronts' in Europe, the Middle East or Asia, the Black Sea region did not witness any military confrontation between the superpowers or their proxies. Surrounded by the Soviets and its allies, Turkey as a NATO member managed to preserve the Alliance's interests without provoking any Russian military reaction in the region. To the surprise of many, about two decades since the end of the Cold War, such stability appears to belong only to the days of superpower rivalry. With the demise of the Soviet Union in 1991, the wider region observed the

*Email: ozgur@bilkent.edu.tr 
emergence of independent states with serious security challenges (Ukraine, Georgia, Moldova, Armenia and Azerbaijan), growing transatlantic involvement by the EU and the NATO and Russia's increasing threat perceptions, destabilizing and unresolved regional conflicts (Abkhazia, Transnistria, Nagorno-Karabakh, Ajaria, South Ossetia, Chechnya), first declining then increasing Russian influence, a strategic role for western energy security, two 'coloured' revolutions (Ukraine and Georgia), the RussiaGeorgia war and various democratization problems and domestic political challenges. In less than two decades, the countries of the Black Sea region went through a difficult period of transformation that increased risks to various forms of security in the region. This article includes a discussion of current security issues in the region and the interests of major actors. A quantitative assessment of military expenditure and force strengths of Black Sea Economic Cooperation (BSEC) members in relation to possible future interstate conflicts in the region follows. The unit of analysis throughout this article is the member states of the Organisation of Black Sea Economic Cooperation, i.e. Albania, Armenia, Azerbaijan, Bulgaria, Georgia, Greece, Moldova, Romania, Russia, Serbia, Turkey and Ukraine. The BSEC member states are preferred as unit of analysis over the Black Sea littoral states (Bulgaria, Georgia, Romania, Russia, Turkey and Ukraine) due to the BSEC's status as the most effective regional organization and the pioneer of regionalization in the Black Sea. Due to the growing involvement of the EU and the USA in regional politics and security matters of the Black Sea region, their positions regarding various issues are also discussed.

\section{Major actors and their security interests in the Black Sea region}

The two events that shaped the current security dynamics of the region are the collapse of the Soviet Union followed by the emergence of new actors in 1991, and the terrorist attacks of 9/11 that resulted in heightened American strategic interests in the region for control of Afghanistan, Central Asia and the so-called greater Middle East. The end of the Cold War made the Black Sea region open to external influences for the first time. The increasing American influence and resistance to it make the Black Sea a stage of great power politics for the first time in modern history.

Complex relations and interests in the region can be simplified if major power centres that perceive important stakes in the Black Sea are defined. There are four major power blocs with varying degrees of influence that push and pull security policy options within the region. These are Russia and its so-called 'near abroad' policy, the EU and its Black Sea littoral member states (Bulgaria and Romania), the USA and its recently increased efforts to penetrate into the region militarily and Turkey maintaining a status quo position on various issues while promoting economic and security cooperation within the region. The complex relations among these four major centres of influence will shape the future of security arrangements and stability in the Black Sea region.

Russian military and political superiority was challenged with the end of the Cold War. Realizing the difficulties of maintaining global political influence and an arms race with the USA with a fragile economy, Russia chose to limit its sphere of influence to what it calls the 'near abroad'. The near abroad, as defined by Russian opinion-makers, includes all the non-Russian ex-Soviet republics in the region where Russia aims to maintain its own political influence (Tsygankov 2006). More specifically, Russia focuses its foreign policy on the South Caucasus, Ukraine and Moldova where most of its military installations are located. Russian opinion on the near abroad 
differs greatly. There are the so-called integrationists (or reformers), such as former President Yeltsin's minister of foreign affairs Andrey Kozyrev who supported integration with the west and a non-interventionist policy in the near abroad, warning that the days of great Russian influence or expansion was over. The second group, which is usually called the balancers (or the Eurasianists), favours a rather limited yet strong Russian influence on issues such as counterbalancing the western powers, military installations in the post-Soviet space, containment of political Islam and border problems in the region. The third group, on the other hand, is called the neo-imperialists and is represented by Russian nationalists such as Vladimir Zhirinovsky and Gennady Zyuganov. This group favours a more aggressive foreign policy: bringing balance back to global politics by maintaining strong Russian influence in the region, whether to the extent of re-building the Russian empire or strengthening closer relations with Slavic countries in the Black Sea, Baltic and Balkan regions. Naturally, the policy recommendations of neo-imperialists evoked the strongest criticism from most of the ex-Soviet republics and the western powers (Tsygankov 2006). For many western analysts, the near abroad policy is nothing more than another attempt to re-establish Russian imperial control in the post-Soviet space and perceived as the main obstacle to the political and economic development of these nations.

More specifically, the events of the last few years strengthened suspicions about Russian aims in the Black Sea region. Russia's involvement in Ukrainian and Georgian domestic politics, its support for the stalemate on unresolved conflicts in the South Caucasus, the use of natural gas as a bargaining chip against the EU, Ukraine and Georgia, and a speech by the President Putin at the Munich Security Conference in February 2007 where he pictured NATO's expansion in Europe as representing 'a serious provocation that reduces the level of mutual trust [between NATO and Russia]' were some of the incidents that added to doubts about Russian influence in the region (Putin 2007). The Russia-Georgia war of 2008 has only exacerbated apprehension about how Russia will use its influence over smaller powers in the region.

To understand the Russian perspective on regional matters, the 2005 remarks by Gleb Pavlovsky, a Kremlin political consultant, on the near abroad policy are useful. Pavlovsky summarized the new Russian near abroad policy with three major points: (1) regime stability in the Commonwealth of Independent States countries is the most important issue for Russia regardless of other concerns and the model for Russia is Belarus in this context; (2) Russia reserves its right to cooperate with the entire political spectrum of neighbouring countries, including both government and opposition, non-governmental organizations, democratic organizations and in-system political groups to promote Russian interests in the post-Soviet space; and (3) Russia still perceives the transatlantic institutions as a threat to its interests both in and out of the region, and it will continue building up its global influence (Socor 2005). All these factors have an implication for Russian foreign policy in the Black Sea: simply put, Russia perceives the transatlantic penetration in the region as a threat to its interests. As such, Russia does and will oppose any further NATO-oriented security instalments in and around the Black Sea.

The second important actor with a stake in the politics of the region is the EU. With the accession of Bulgaria and Romania to the Union in January 2007, the EU has become an important actor in the Black Sea context. The EU aims to increase its presence and influence in the Black Sea through its regional programmes - the European Neighbourhood Policy and the Black Sea Synergy. With the German presidency in 2007, the Union began showing an unprecedented interest in Black Sea politics. The 
EU has two major interests along with many other minor ones in the region. First, the EU aims to secure energy supplies from the region to its markets. European dependency on Russian energy creates a vital need for transiting gas and oil to the EU markets through the Black Sea and Turkey. Second, many policy-makers are convinced that the stabilization and democratization of the ex-Soviet republics in the region will strengthen the security of Europe. Many experts see the fragile republics in the region as sources of instability, conflict and terrorism that have the potential to affect the EU's security (Aydin 2005). Therefore, the EU aims to support democratisation, good governance projects and civil society within these countries (Aydin 2004). These policies of the EU and its support for the Orange and Rose revolutions in Ukraine and Georgia provoked a number of reactions from Russian politicians.

The third power that has increasing strategic interests in the region is the USA. Observing the delicate balances of the Cold War, the USA and the NATO did not have any active role in the Black Sea region. In fact, even in the first decade of the postCold War era, the USA maintained a rather low profile when Black Sea issues were considered. However, with the events of $9 / 11$, transatlantic security focus shifted from Central and Eastern Europe to what is called 'greater Middle East' and 'wider Black Sea'. The USA's interests in the region can be summarized as follows. First, American policy-makers argue that the original impetus for the current debate on American involvement in the region came from Europeans, specifically Bulgaria and Romania. According to this point of view, EU and NATO enlargement should not stop at the western shore of the Black Sea, it should instead spread over to the eastern parts of the region. Drawing analogies from the period immediately after Second World War in Western Europe, and the post-Cold War period in Central and Eastern Europe, the advocates of this view propose that peace and stability can be achieved in other parts of the region as well. The coloured revolutions in Ukraine and Georgia, in particular, strengthened this line of thinking and raised hope for similar democratisation in other parts of the region (Asmus 2006).

Second, the USA recognizes the region as a strategic asset for the control of the so-called 'greater Middle East'. To increase its influence over the region and facilitate the war on terrorism, the USA's new security perceptions require control over the wider Black Sea with its strategic position between Europe and the Middle East. These aims, of course, can only be achieved via an increased political and military presence in the region. The USA already attempted to extend the Operation Active Endeavour to the Black Sea. ${ }^{1}$ However, Turkey proposed that Black Sea Harmony operated by Turkish Navy is already committed to the same purposes in the region. ${ }^{2}$

The third major reason that the USA has shifted its attention to the region is energy security. For the USA, minimising the western markets' energy dependency on Russian energy is of great importance. Therefore, the USA aims to diminish the Russian role as major energy supplier to the markets. Thus, the Black Sea becomes vital as the key transit region for natural gas and, to some extent, oil. Though American involvement in the Black Sea is new, it could potentially become more influential and draw a greater reaction from Russia.

The fourth actor that has an important influence over the future of the Black Sea security issues is Turkey. Since the end of the Cold War, Turkey has championed regional cooperation schemes, both on economic and security matters. However, with the changing security environment after 9/11, Turkey's uneasy relations with the USA regarding Iraq and growing tensions between Russia and the EU-NATO couple led Turkey to follow a policy of caution on matters concerning the Black Sea. In order to 
prevent existing regional initiatives (e.g. BSEC, Black Sea naval task force [BLACKSEAFOR] and Black Sea Harmony) from being harmed by the new rivalry between the west and Russia, Turkey has chosen to defend the status quo in the region.

The concerns of Turkish policy-makers about emerging tensions between the transatlantic actors and Russia are twofold. First and foremost, Turkey's concerns focus on the maritime security domain. Maritime security in the region is largely shaped by the Montreux Convention of 1936 that governs the regime of the Turkish Straits (Bosporus and Dardanelles). This sui generis treaty recognizes the sovereignty of Turkey over the two straits, allows for free passage of commercial ships and limits the stay of military ships from non-littoral states to 21 days in the Black Sea. This agreement had the support of all the littoral states because it limited the military activities of non-littoral states in the region. During the Cold War, the USA and the NATO also favoured the agreement because it limited the ability of the Soviet Navy to shift forces to the Mediterranean over a short period of time, due to the limitations on the number of warships that can pass the straits in a certain time. However, with the changing security dynamics, Bulgaria and Romania brought up the possibility of relaxing the terms of Montreux, in favour of a large US Navy presence in the Black Sea. Of course, American policy-makers also support such a plan. These suggestions are strongly opposed by Turkey for one major reason: Turkey fears this can change the balance of power in the region and make Russia feel even more contained, thereby destabilising the region even further. As a result, more than seven decades of peace and stability in the maritime security of the Black Sea might be threatened. The Turkish position on expanding the NATO forces to the Black Sea is that Turkey as a NATO member is in favour of maintaining maritime security activities in cooperation with both NATO and the littoral states. For Turkey, a change in the status quo might be more costly than beneficial for all actors in the region.

Secondly, Turkish policy-makers suggest that any security arrangement in the region must be agreed upon by all littoral states to maintain the balance in the region and prevent further threats to the already volatile regional politics. Of course, this position is mostly related (but not limited) to Russian concerns. Turkey aims to include every littoral state in each security arrangement. What Turkey emphasises most is that Russia must be incorporated into security arrangements in order to protect the fragile balance and prevent more assertive Russian foreign policies.

Therefore, Turkey initiated a BLACKSEAFOR in 1998 to reinforce regional security arrangements. BLACKSEAFOR was formally established in April 2001 to perform search and rescues operations, humanitarian assistance, mine countermeasures and environmental protection (Simon 2006). To improve the on-call assistance mechanism of BLACKSEAFOR and meet new asymmetric threats, Turkey began executing a new security initiative called Black Sea Harmony in March 2004. The aim of this initiative is similar to NATO's Operation Active Endeavour in the Mediterranean Sea (Karadeniz 2007). Turkey continues its multilateral approach to Black Sea security and invited other littoral states to participate. After Russia, Ukraine is also likely to join the initiative. This brief discussion on the interests of major powers helps assess the military balance and security threats regarding the region.

\section{The military balance in the Black Sea}

In this section, a quantitative comparison of military expenditure trends and force strengths of BSEC member states is presented. The focus is the absolute annual 
military expenditure and its percentage of GDP, along with a manpower and equipment comparison of navies, armies and air forces of the 12 countries. Such an analysis is useful because it examines measurable facts, instead of the 'intentions' or 'strategies' (Cordesman 2004) of actors that some analysts assume. ${ }^{3}$

During the Cold War, the military balance in the Black Sea region favoured the Soviet Union and the countries within its sphere of influence. In the west, east and north of the Black Sea, the Soviet Union, Romania and Bulgaria were the Warsaw Pact powers while the NATO member, Turkey, guarded the southern flank of the western alliance. Owing to its rather 'closed' nature to outside influences and the Montreux Convention that limits the access of foreign navies to the Black Sea, the region enjoyed stability despite the obvious superiority of the Soviet naval forces. However, with the downfall of the USSR, the balance shifted to the detriment of Russian interests. Especially during the 1990s, due to economic difficulties and the loss of its influence on other littoral states (e.g. Ukraine), Russian military superiority was diminished, if not totally challenged. In this section, the material capabilities of the six littoral states, the military balance and the expenditures of the 12 BSEC member states are discussed.

One of the methods to compare the material 'power' of states concerning security and military issues is to measure their relative material capabilities. Despite the relative decrease compared to the Cold War years, it would be a mistake to underestimate Russian capabilities in this respect. Figure 1 shows the national capabilities distribution of the littoral states in 2001, the latest available year in the data-set. That is, this figure shows the percentage share of each littoral state's 'material capabilities' (Singer, Bremer, and Stuckey 1972) within the Black Sea region. ${ }^{4}$ Even such a simple analysis illustrates the importance of Russian influence in the region. About $60 \%$ of

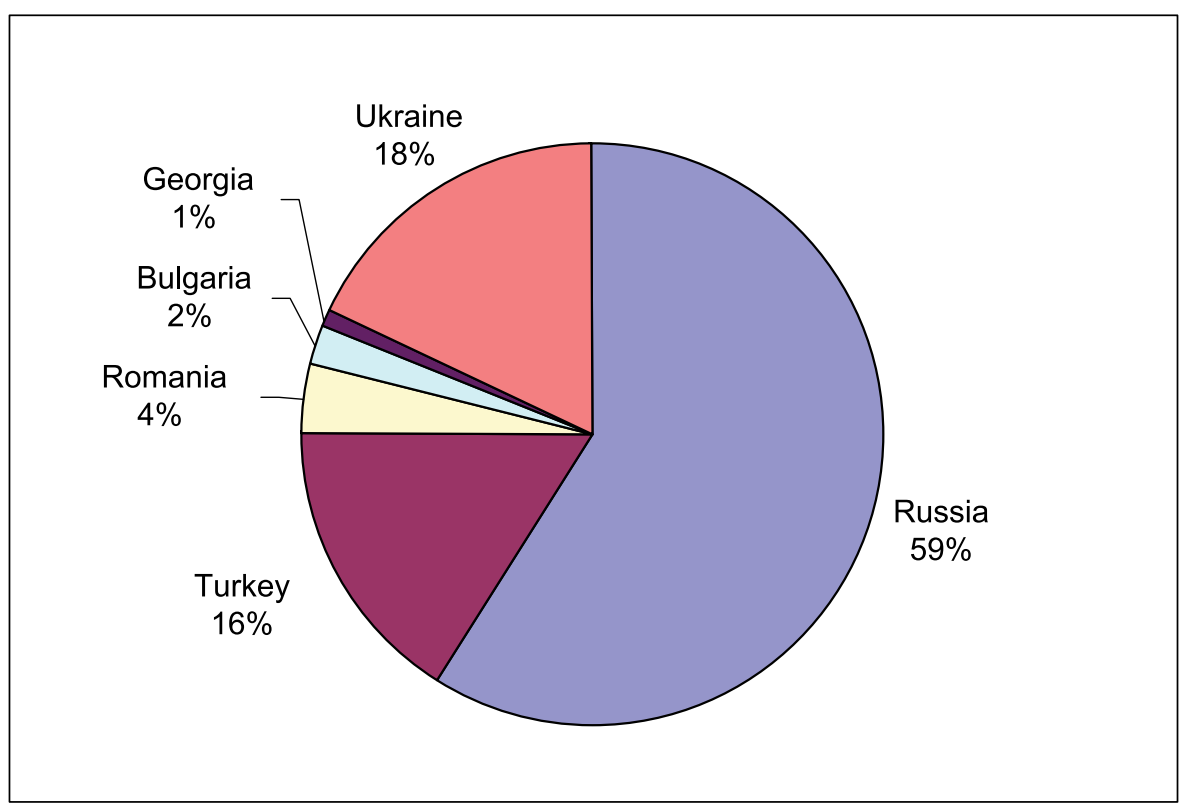

Figure 1. A comparison of national capabilities of Black Sea littoral states 2004 (Singer, Bremer, and Stuckey 1972). 
total capabilities belong to Russia while Ukraine and Turkey each posses less than one-third of Russian capabilities each.

Material capabilities are not identical to power. To analyse capabilities is not to deny the influence of other factors providing security such as multilateral security institutions. Still, this analysis is useful because it gives an idea as to why there is such a strong Russian influence in the region. If power can be defined as a nation's ability to exert and resist influence, understanding the material indicators that lie behind such influence is of utmost importance to understanding the regional dynamics.

Another way to analyse the nature of balance of power in the region is by studying military spending trends. Usually, abrupt increases in military expenditure in a dyad of states can be an early indicator of military confrontation. In some cases, slow but steady increases in military spending of two or more countries give a similar warning. Therefore, an analysis of military sizes and expenditure of regional powers may help conflict prevention. Figure 2 shows estimates of military expenditure by each BSEC member states in the period from 1998 to 2007 based on data provided by SIPRI (Stockholm International Peace Research Institute 2009). Evidently, Russia leads military expenditure in the region with a little over US\$35 billion (in constant 2005 dollars) in 2007. Russia is followed by Turkey (US\$11 billion) and Greece (US\$9 billion). This shows an important aspect of military balance in the region: Russia and Turkey maintain the largest military capabilities in the region. An interesting trend in Figure 2 is that Russian military spending has been increasing steadily over the last decade. Towards the end of the Cold War, Russia maintained an unsustainable military expenditure which was US\$218 billion per year in 1988 equalling approximately $16 \%$ of its GDP (SIPRI 2009). For many analysts, this tremendous military spending led to poverty and was the main reason that the people of the Soviet Union toppled the communist regime. With the end of the Cold War, Russian military spending significantly plummeted. In 1998, Russian military spending was as low as US\$13 billion per year. As gas and oil revenues grew, Russian military spending picked up.

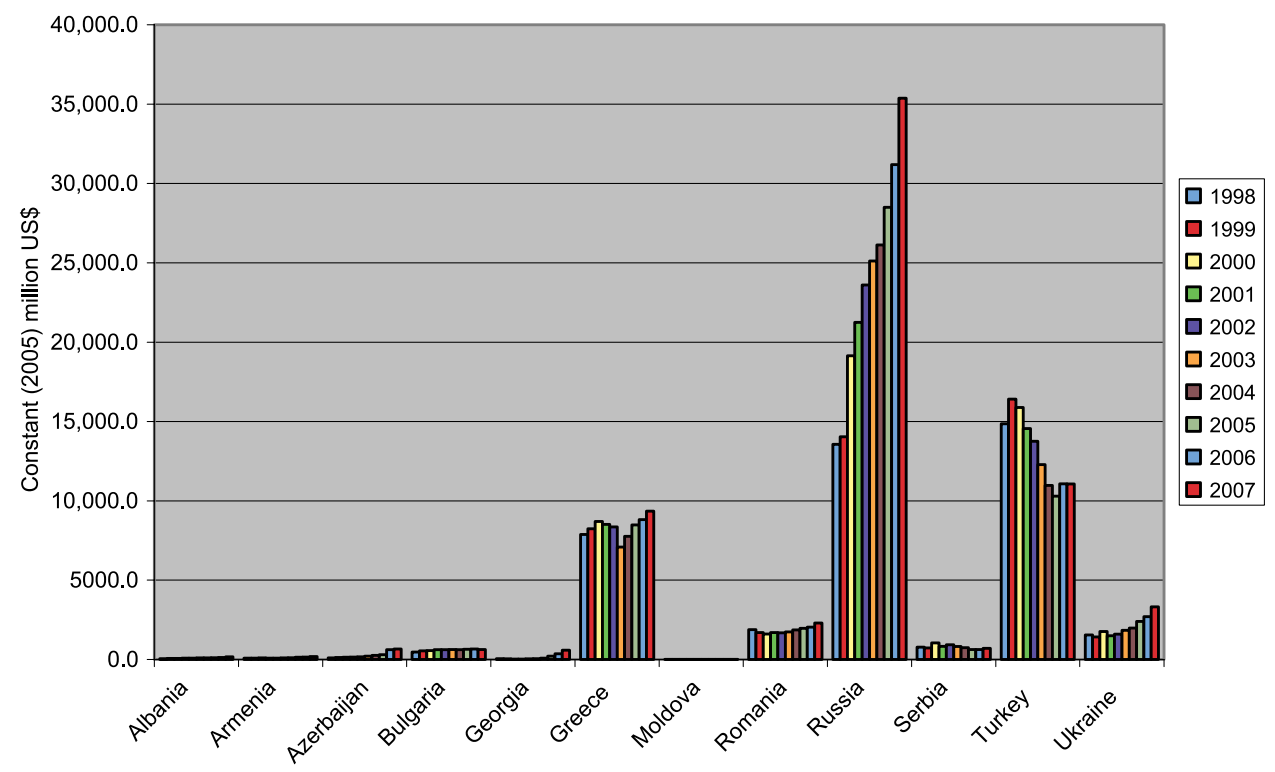

Figure 2. Military expenditure in BSEC members 1998-2007 (SIPRI 2009). 
Compared to the Cold War era, Russian expenditure is still low considering the size of its armed forces. However, the trend shows a steady increase reflecting Russian aspirations to strengthened military power. After such a steady increase, one can theoretically expect more use of force from Russia. Sudden jumps in military spending are also to be observed carefully. Georgian military spending increased from US\$58 million in 2002 to US\$592 million in 2007, in only five years (SIPRI 2009). The Military Balance (International Institute for Strategic Studies 2009) predicted that Georgian military expenditure was around US\$1.1 billion in 2008, 20 times more than just a decade ago. The events of August 2008 are an example of the relationship between higher military spending and imminent military conflict.

Military expenditure as a percentage of GDP in the region is given in Figure 3 (SIPRI 2009). This analysis shows the percentage of the national income that policymakers are willing to spend on defence. Usually, in less militarized states, one can expect this figure to range from $2 \%$ to $4 \%$. Figure 3 shows similar trends in terms of military expenditure as a percentage of GDP. Russia, Turkey and Greece spend about $4-5 \%$ of their GDP on the military. When longer term trends are observed, one can see that the military spending of the Black Sea countries has been quite stable in the last decade, from $1 \%$ to $5 \%$ of their GDPs. Relatively constant nature of spending behaviour suggests there is no region-wide arms race. However, there are two exceptions to this. The military spending of Georgia and Azerbaijan show steep increases, both in terms of absolute measures and relative to their GDPs. In 2000, Georgia spent about half a percent of its GDP on defence. Since then there has been a steady increase and an abrupt jump after 2004. In 2005, Georgia's military expenditure jumped from $1.4 \%$ to $3.3 \%$ of the GDP, and in 2006 to a record 5.2\%. Azerbaijan's increase in spending as a size of GDP seems less rapid. However, one should consider that with higher oil prices, Azerbaijan's GDP increased very rapidly as well. Azeri GDP grew from 27 to 40 billion US dollars from 2007 to 2008 (International Institute for Strategic Studies 2009). Therefore, even though the percentage of GDP spending

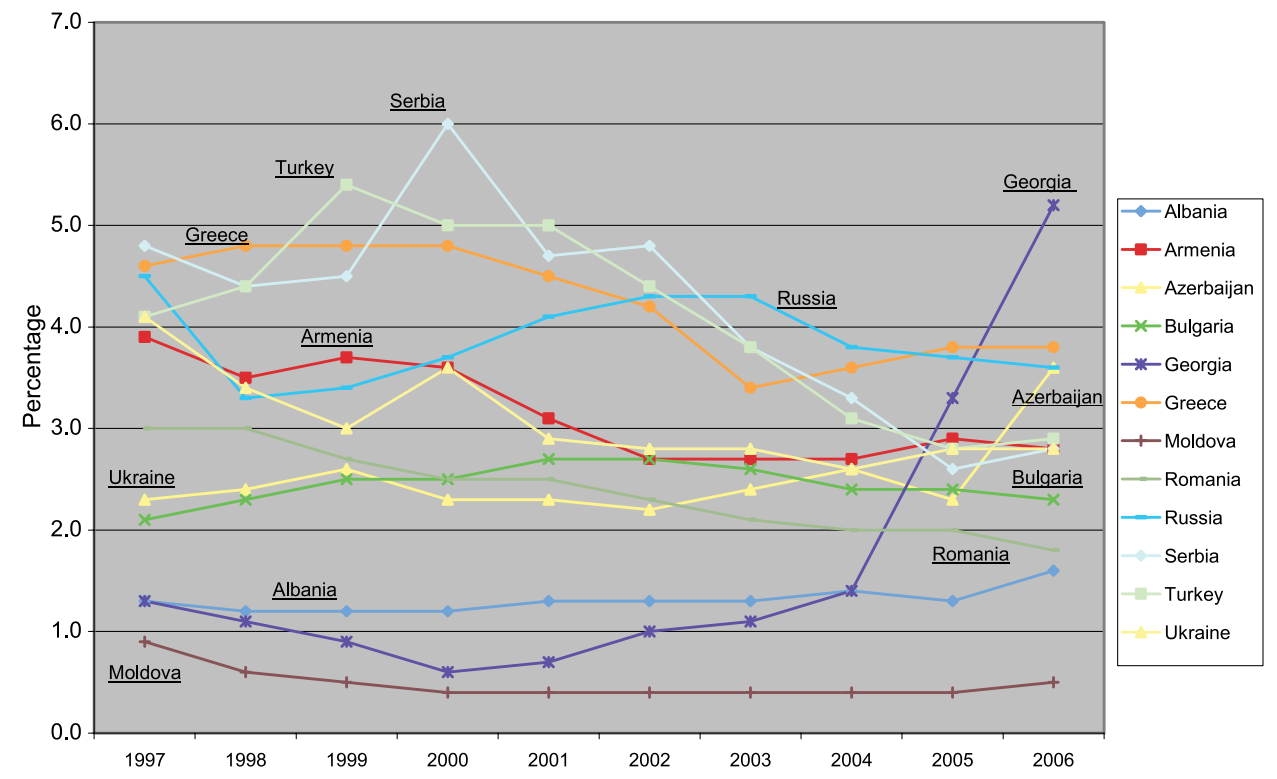

Figure 3. Military expenditure as share of GDP 1997-2006 (SIPRI 2009). 
shows a normal progress, in absolute measures, from 2004 to 2007 Azerbaijan's defence spending jumped from 260 to 667 million US dollars (SIPRI 2009). In 2008, Azerbaijan's defence budget was estimated to be a record US\$1258 million by The Military Balance (2009). Such increases in military spending boosted the confidence of some hawks in Georgia that it could prevail in a military confrontation against Russia (International Crisis Group 2008a). In fact, the August 2008 war had disastrous consequences for the country. Therefore, the international community should take unusual increases in military spending in the Black Sea region as an early warning for military confrontation, especially with regard to Azerbaijan and Armenia in the near future.

Lastly, a brief comparison of the military sizes of the regional actors will be presented. Table 1 shows the military personnel capacities of the 12 BSEC member states (International Institute for Strategic Studies 2009). Russia's vast army, with an enormous reserve capacity of some 20 million, dominates the regional balance of power. This perhaps explains why other smaller powers aim to balance the Russian effect in the region with a USA-NATO presence. The second largest personnel capacity is the Turkish armed forces with more than half a million active and 378,700 on reserves. The other significant forces in the region are Ukraine and Greece, although they are lagging far behind the first two. Finally, Figure 4 illustrates total military spending of the BSEC member states in comparison with the other regions in the world. The figure shows that even with the inclusion of substantial Russian spending, the Black Sea is not a highly militarized region compared to others such as the Middle East.

Tables 2, 3 and 4 compare navies, armies and air forces in the region by military equipment (International Institute for Strategic Studies 2009), respectively. A similar balance can be observed in these categories as well. Russia and Turkey maintain the

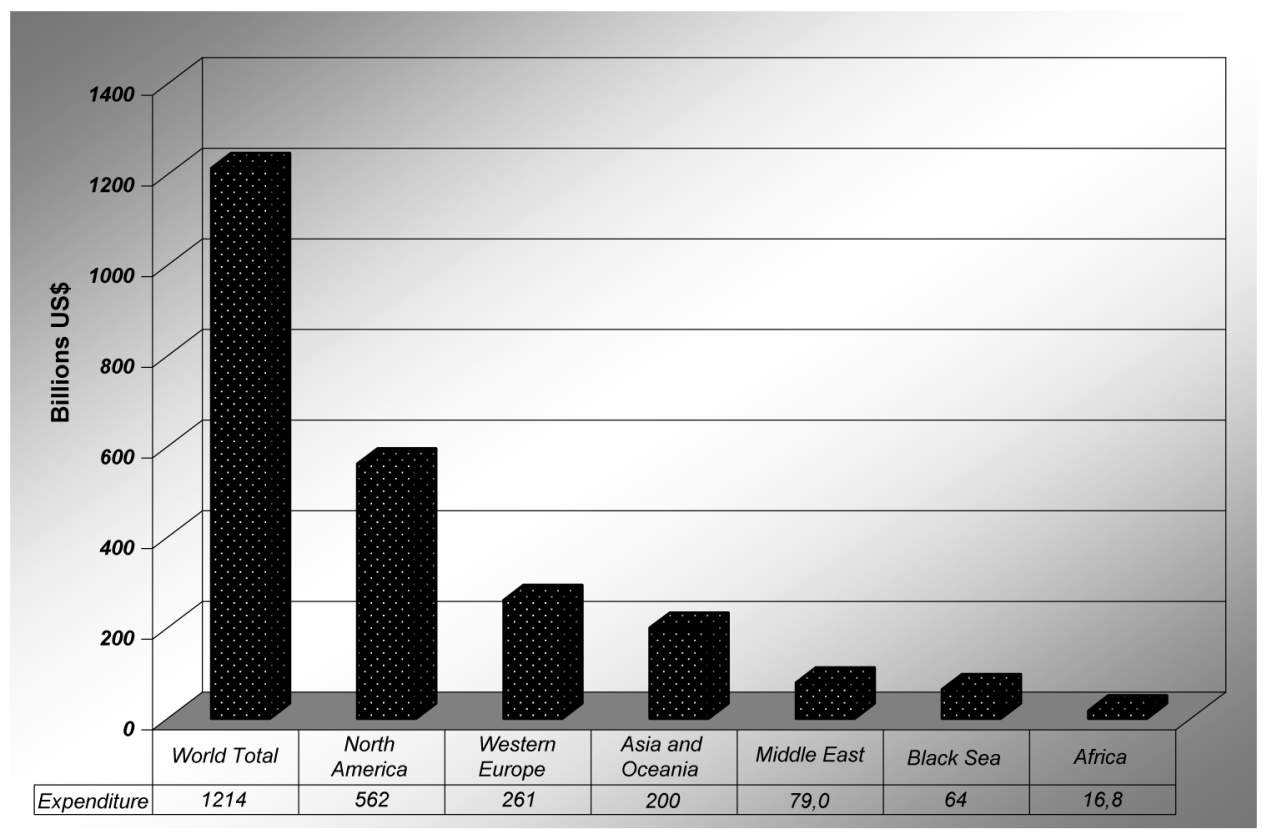

Figure 4. Military expenditure by some world regions in 2007 (SIPRI 2009). 


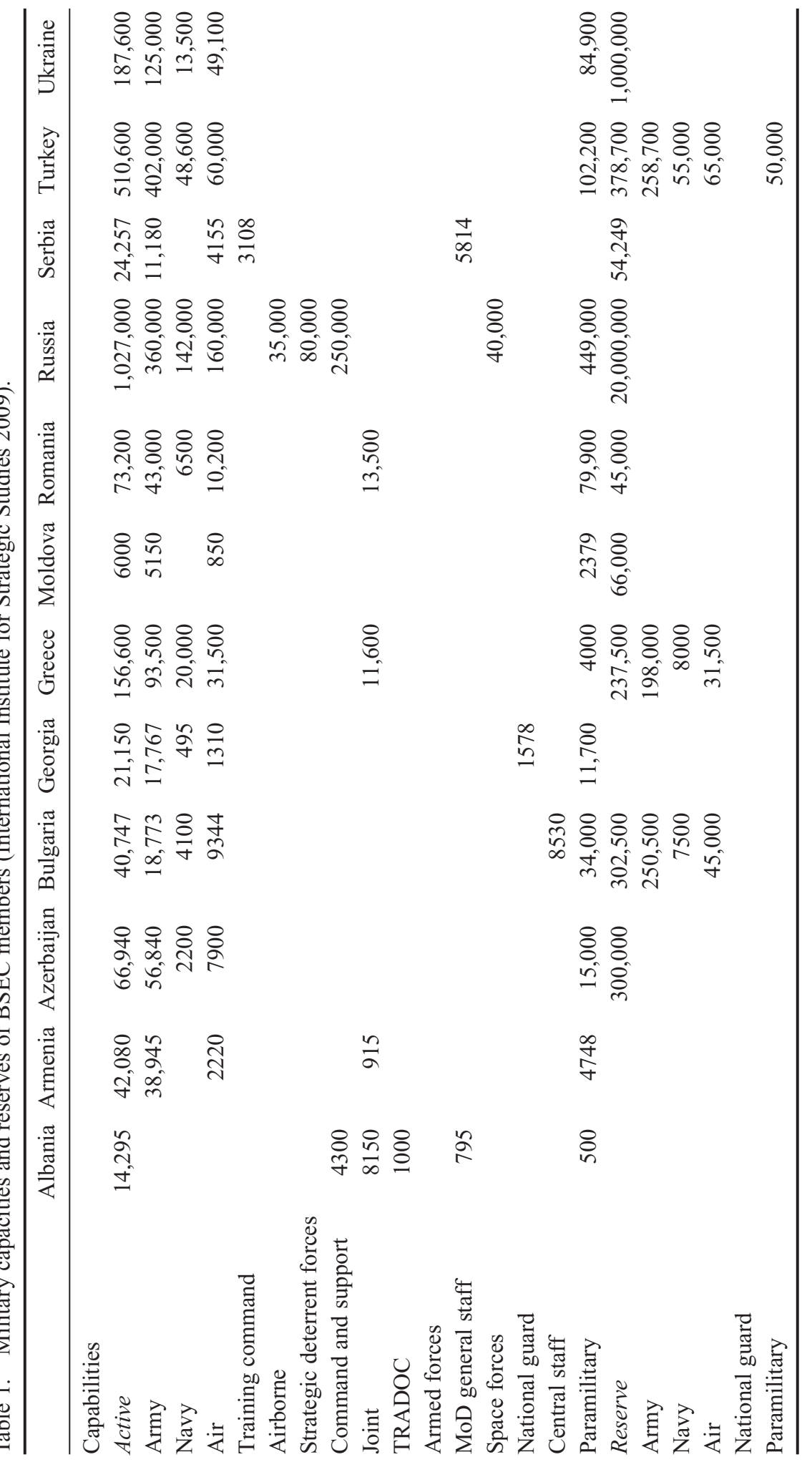




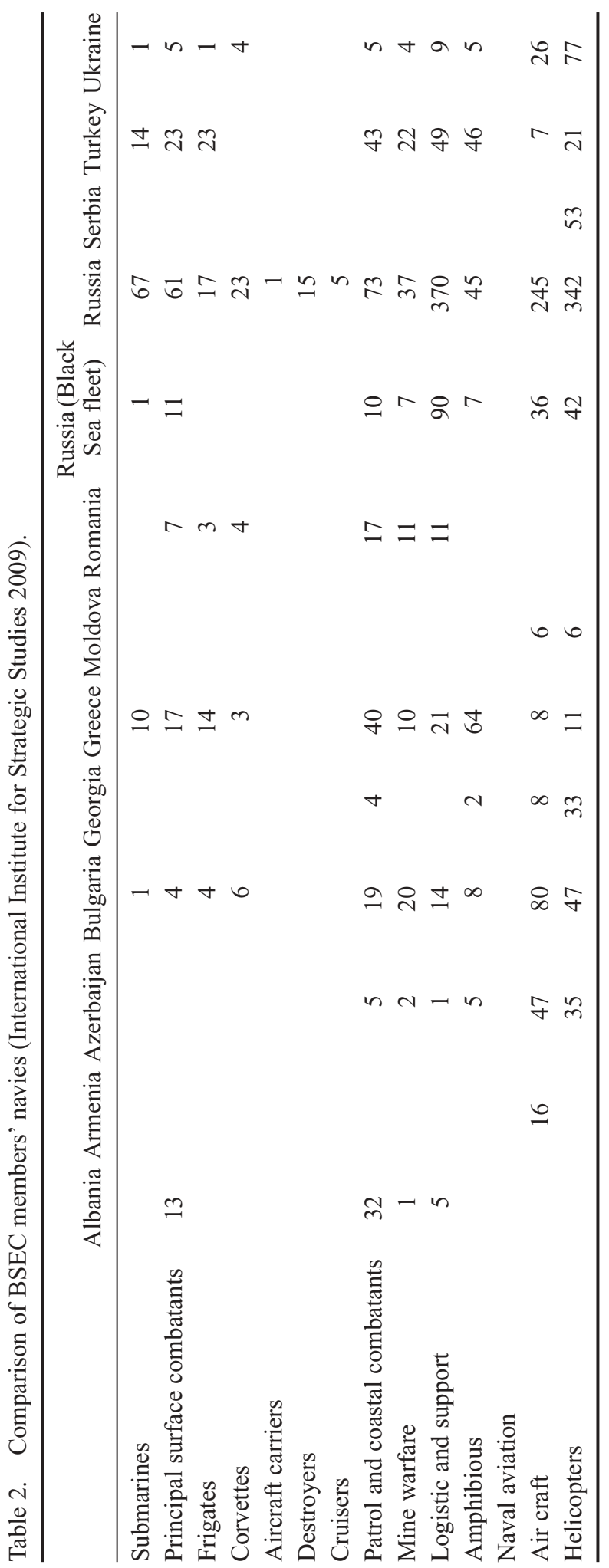



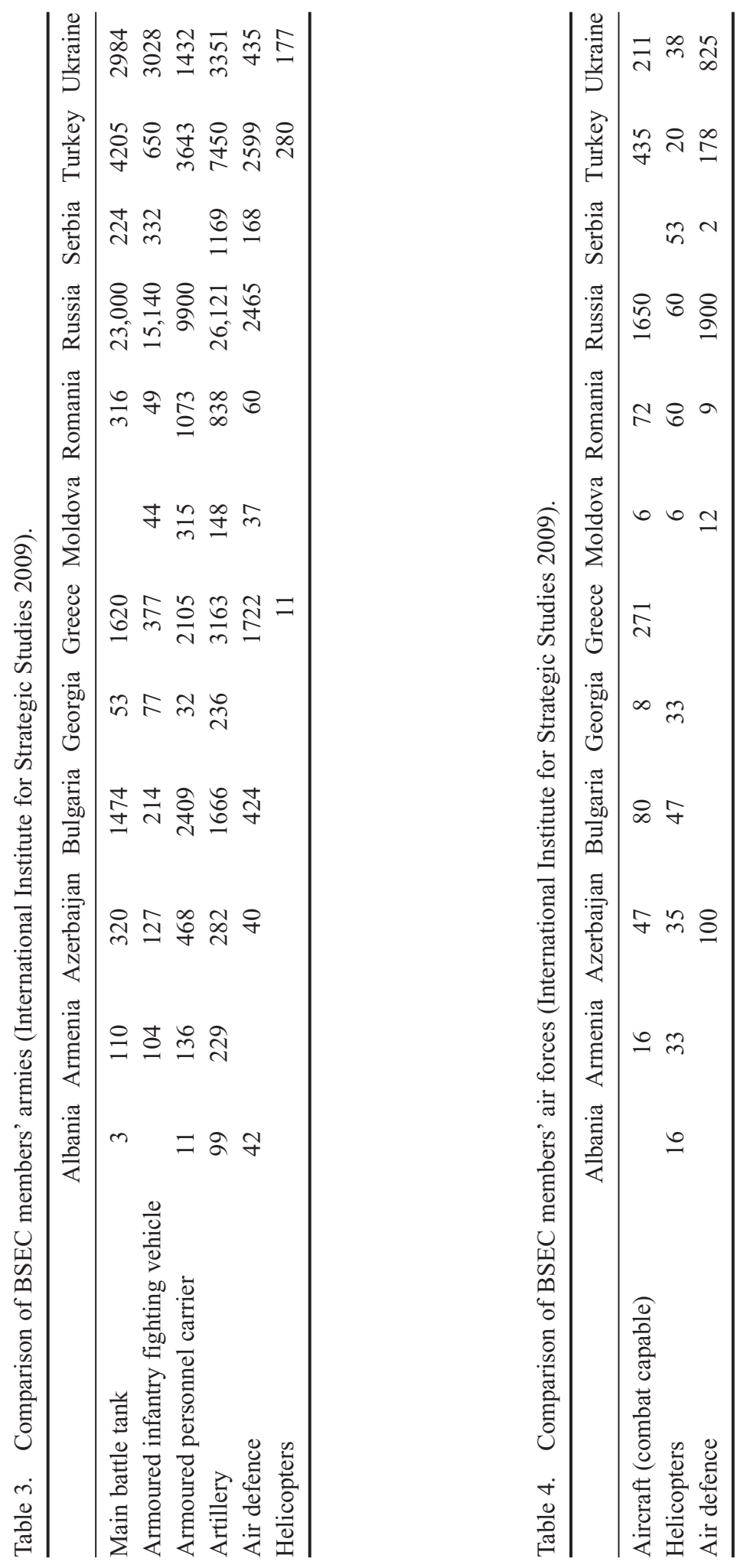
leading armed forces in the region in terms of military equipment type and quality. The naval forces of the littoral states are depicted in Table 2. The Russian Navy is by far the strongest. However, when Russian forces are reviewed, one must consider the vast size of Russia and how these forces are dispersed over the largest land mass in the world. Therefore, Russia's Black Sea Fleet is included as a separate column in the table. When such a comparison is made, the Turkish Navy and armed forces seem to have a similar conventional capacity to that of Russia. ${ }^{5}$

All things considered, military security in the Black Sea can be provided by a few forces: Russia, Turkey and to some degree Ukraine and Greece. Perhaps this also explains why Turkey has been willing to incorporate Russia - and Ukraine - in every regional security-building initiative. This review shows that the provision of security in the region is more likely to work if it is multilateral and non-exclusive. Therefore, admitting Georgia and Ukraine to NATO without agreeing with Russia may prove even more problematic than some analysts suggest. Also, this review shows that some states in the region have begun to perceive engagement in militarized conflict as a means to resolve problems; this is likely to cause interstate wars, as it did between Georgia and Russia. Such states and their military expenditure, and the nature of such spending, must be closely observed.

\section{The Russia-Georgia war and other potential interstate armed conflicts in the region}

Early in the morning of 8 August 2008, the Georgian army began a large-scale attack on the break-away region of South Ossetia. Almost instantly, Russian troops started a counterattack against Georgian troops in the region, conducting air raids further in the country, and the Russian Navy blockaded the Georgian Black Sea coast. On 12 August, Russian-backed militia in Abkhazia attacked the Kodori Gorge held by Georgian troops and advanced into Georgia. On 15 August, Georgia signed an EUbrokered ceasefire agreement with Russia. In about a week-long conflict, Georgia was totally expelled from South Ossetia and Abkhazia and suffered losses in territories controlled by Tbilisi (BBC News 2008). On 26 August 2008, Russia recognised the independence of South Ossetia and Abkhazia, which was followed by the Georgian government's announcement that these regions are 'territories occupied by Russia' (Civil Georgia 2008).

With the August war, Russia engaged in its first conventional use of force since the Cold War and established new protectorates. Russia's response to Georgia's attacks was condemned and called 'disproportionate' by the USA and the EU. Russia argues that the operations were meant to protect its own citizens in these regions, yet this argument has not convinced the various actors in the region. On the contrary, many perceive this conflict as a sign of a more assertive, if not aggressive, Russian foreign policy and Russia's ambition end transatlantic penetration into the ex-USSR space.

The August war has major implications for the security and stability in the Caucasus and the Black Sea region. It was the first major interstate conflict since the Nagorno-Karabakh war that ended in 1994 and the first major armed conflict in a decade since the second Chechen war. Implications of this conflict can be analysed at three levels. First, from the perspective of Georgia and other consolidating democracies, the war was a major blow to those aiming to integrate into transatlantic political and security arrangements. The euphoria from the Orange and Rose revolutions ended 
and hopes to pursue democratization and liberal economic reforms under the protection of the USA and the EU were curbed. The August war sent a strong message to smaller powers in the region that consider western models of political and economic change in their countries. According to this point of view, Georgia was actually penalised by Russia for its NATO membership aspirations, liberal reforms and close relations with the USA and the EU, not for attacking Tskhinvali. Georgian President Saakashvili's power to transform his country was seriously damaged and prospects for reform look dimmer than ever. In countries such as Ukraine, policy-makers feel even more constrained by Russia's possible response to their NATO or EU bids.

At the regional level, the Russia-Georgia war proved that interstate war is still on the table as a policy option. That is, Russia showed it will not hesitate to use overwhelming force when its interests are at stake. History shows that once use of force is 'normalized' as a tool of foreign policy-making in a region, other actors also tend to resort to it. Therefore, with or without Russian involvement, engaging in armed conflict between states is more likely than before in the region. This is especially true if there is a lack of hegemonic powers preventing conflicts. In the Black Sea, Russia as the hegemonic power showed a willingness to use force as a means of settling disputes. Therefore, although it is early to comment, this war may have destabilised the wider Black Sea region beyond first estimates. Russia also hinted that it will only allow limited sovereignty for ex-Soviet republics in the region, especially on securityrelated matters (International Crisis Group 2008b). Some analysts argue that policymakers in Ukraine, Azerbaijan, Armenia and Moldova already fear such Russian interventionism (Nichol 2008). Although Russia has no legal right to intervene in the foreign policy-making of sovereign states, it will do so in the future, especially on issues like NATO membership. Another bleak implication of the war for states like Georgia or Ukraine is that they cannot rely on western powers for their countries' defence.

In terms of global politics, the war showed the limits of the transatlantic sphere of influence. It appears that Russia is determined to develop policies against the so-called transatlantic push beyond Central and Eastern Europe. In particular, NATO membership prospects for Ukraine and Georgia look more problematic than ever. NATO declared during the Bucharest summit in 2008 that these countries will become members. Some NATO members are against this prospect in the near future; important member states such as Germany, France and Italy opposed the idea of initiating Membership Action Plans for the two Black Sea littoral states. It seems that many important European actors, especially those with local commercial interests, are not willing to challenge Russia 'head on' in the region (Triantaphyllou 2008). This indicates yet another transatlantic divide over security policy. Due to higher volumes of trade with and energy dependency on Russia, major EU powers were opposed to the membership of Ukraine and Georgia. After the war, admitting Georgia to the Alliance seems like a bigger liability for NATO than before since its two regions are under Russian control.

The war also reconfirmed the sceptics' view regarding the United Nations' (UN) capabilities to stop wars when the interests of one of the five permanent members of the UN Security Council are at stake (International Crisis Group 2008b). The EU was able to provide a more dynamic source of diplomacy during the war than the UN. On the other hand, the August war may herald the end of the unipolar world in terms of the systemic structure in international relations. Two decades of unipolarity in the post-Cold War era may have ended with Russia's military intervention. Theoretically, 
Russia's use of force seems to confirm the neorealist prediction that we will observe more balancing behaviour from great powers like Russia and China against the USA in the near future. It is too early to say whether the Russia-Georgia war was the breaking-point signalling the dawn of the second Cold War or a different systemic structure such as bipolarity or multipolarity. But surely it is the first act of balancing by Russia that involved the use of force since the end of the Cold War. As early as a decade ago, neorealists such as Kenneth Waltz predicted such balancing behaviour due to NATO expansionism:

The reasons for expanding NATO are weak. The reasons for opposing expansion are strong. It draws new lines of division in Europe, alienates those left out, and can find no logical stopping place west of Russia. It weakens those Russians most inclined toward liberal democracy and a market economy. It strengthens Russians of the opposite inclination. It reduces hope for further large reductions of nuclear weaponry. It pushes Russia toward China instead of drawing Russia toward Europe and America ... In June of 1998, Zbigniew Brzezinski went to Kiev with the message that Ukraine should prepare itself to join NATO by the year 2010. The farther NATO intrudes into the Soviet Union's old arena, the more Russia is forced to look to the east rather than to the west. (Waltz 2000, 22)

The USA's and the EU's reaction to Russia's intervention were quite weak, limited to some 'strong' rhetoric. There were discussions about a number of possible sanctions against Russia immediately after the war, but EU and US decision-makers did not seem to reach a firm conclusion (Nichol 2008). These sanctions were downplayed by Russian Prime Minister Vladimir Putin and never applied by the USA and the EU as of December 2009. However, the sudden drop in the Russian stock market, foreign currency, foreign investment and increase in domestic bond yield during and after the war shows that Russian political decisions influence its economic and financial stability (International Crisis Group 2008b). Such instability could lead to domestic criticism for the Russian administration's aggressive foreign policy.

The future holds the serious risk for more conflicts in the region. Russia's strong conviction to defend its interests thorough the use of force could result in more interstate militarised conflicts in the region. One of greatest risks lies in another war between Russia and Georgia. Both countries seem to hold on to their hardliner positions regarding the South Ossetia and Abkhazia issues. Considering that the level of tension between the two countries is still quite high, any military exchange around the demarcation line may lead to another deadly conflict. Military build-up from Russia and Georgia at the border of Abkhazia during 2008 had already been worrying international analysts about a possible conflict in the region (International Crisis Group 2008a). Instead, it was the military build-up in and around South Ossetia that sparked a conflict. Of course the Georgian side will consider future actions more carefully after the clear defeat and loss of substantial military capacities to Russian forces. Yet, in the mid-run, conflict between Russia and Georgia is still a great risk for the Black Sea region.

Relations between Russia and Ukraine also pose a security risk in the Black Sea. In fact, Russia's relations with Ukraine have been as problematic as its relations with Georgia. The Russian reaction to the Orange Revolution in Ukraine has been to threaten and bully, in both political and economic spheres. Russian influence over democratic politics in Ukraine should be observed carefully. Perhaps the biggest challenge will be about security arrangements. Russia has repeatedly asserted that 
Ukraine's membership to NATO is perceived as a direct threat and that it will be forced to react. Moreover, Russia can mobilize the Russian-speaking minority in Crimea and Eastern Ukraine against the government in Kyiv. An International Crisis Group publication quoting a Russian newspaper, Kommersant, claimed that Vladimir Putin told US President George W. Bush in the Bucharest NATO meeting in 2008, 'You understand, George, that Ukraine is not even a state! What is Ukraine? Part of its territory is Eastern Europe, and another part, a significant one, was donated by us!' The paper also claimed that during the same conference Putin hinted that if Ukraine is admitted to NATO, it 'can simply cease to exist' (International Crisis Group 2008 b, 17). We can expect relations to worsen if Ukraine does not extend the lease of Russian Navy base in Sevastopol, which will end in 2017. The victory of Viktor Yanukovych in the Ukranian presidential elections of early 2010, coupled with the deal to extend the lease for the Russian Navy base in Sevastopol for another 25 years and a lagging interest in NATO membership, implies that over the short- to mid-term a number of possible conflicts between Russia and Ukraine have been averted. Nevertheless, Ukraine's neighbour Moldova can also face Russian military intervention due to risks involved in the Transnistria conflict.

Finally, the Nagorno-Karabakh conflict between Armenia and Azerbaijan poses a great threat to the stability of the region. The last few years in particular have witnessed a huge military build-up on both sides, especially Azerbaijan. Figure 5 shows the comparative military expenditure between two countries since 1997. In 1997, the military expenditure of two countries was about the same. Since then, there has been a gradual and substantial capacity-building for Azerbaijan that more than tripled Armenia's annual expenditure by 2007. From 2002 to 2007, Armenia doubled its defence budget while Azerbaijan's has more than tripled. Both countries seem to be in an arms race led by Azerbaijan, thanks to revenues from its rich fossil fuel reserves. Such a military build-up does not bode well for Armenian-Azeri relations, the resolution of the conflict through peaceful means and the stability of the region. Such abrupt increases in military expenditure are usually indicative of plans for

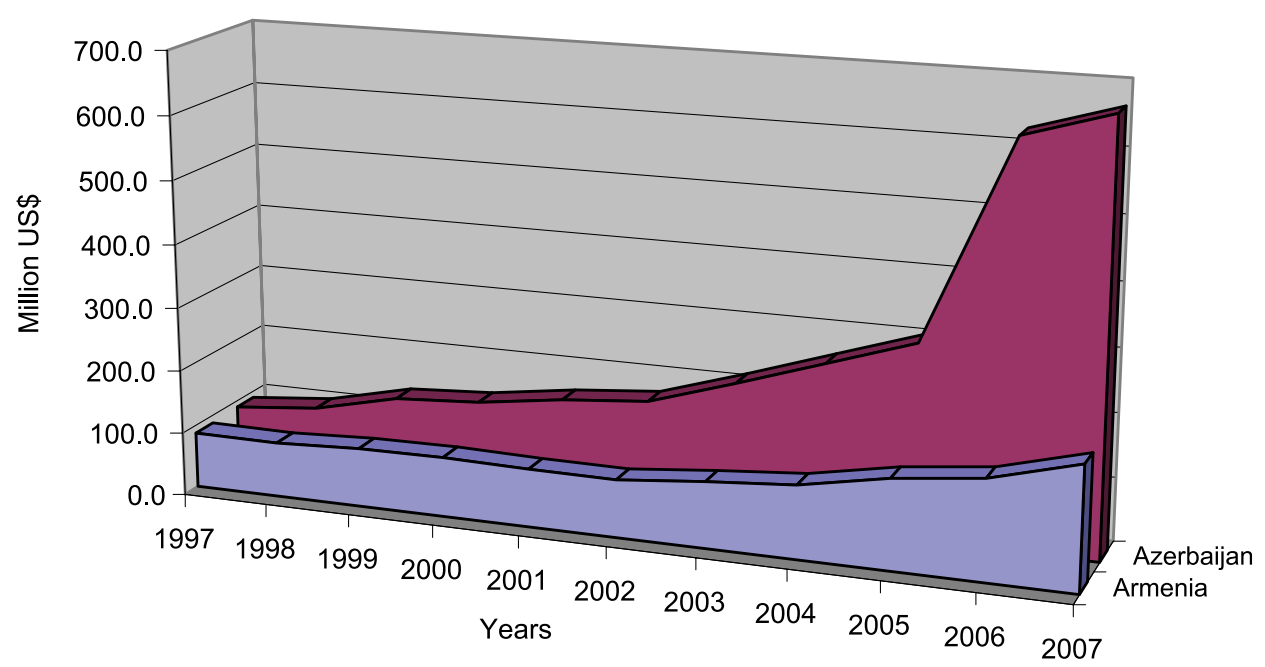

Figure 5. Comparison of military expenditure: Armenia and Azerbaijan (International Institute for Strategic Studies 2009). 
military engagement with rivals. Azeri President Aliyev's speech before a meeting between Azerbaijan and Armenia over Nagorno-Karabakh in November 2009 is illustrative: 'If this meeting ends without a result then our hopes in the negotiating process will be exhausted in which case we will not have any other choice. We have the full right to liberate our lands by military means' (Olson 2009). In the same speech President Aliyev also added, 'We have strengthened our armed forces with billions of dollars investments over years in case there will be no diplomatic solution with Armenians' (Hacioğlu 2009). In such a militarized conflict, Azerbaijan might prove superior to Armenian capabilities. However, Armenia will probably be supported by Russian troops in the region which would have spillover effects for the stability in the whole region. Such a conflict with Russian involvement would only make the destabilized region even more insecure.

To sum up, the August 2008 war has had enormous implications for the future of security in the Black Sea region. Russian influence, which already overwhelmed regional powers, is even greater than before. The war also strengthened the perception that military confrontation is still a 'normal' policy to settle disputes. The further destabilization of the region is thus possible if the regional actors accept the use of force as a means to settle disputes.

\section{Conclusion}

After two decades of political and economic transition, the Black Sea region seems as unstable and insecure as before. In fact, the so-called 'frozen conflicts' proved to be 'not frozen' and pose the risk of turning into both interstate and intrastate wars. The ambitions of the USA-EU couple to integrate the region to transatlantic institutions and Russia's strong resistance to such efforts have made the region a playground for great power politics. Instead of advancing 'a culture of concrete cooperation', the region seems to slide into the 'geopolitical/geostrategic' approach (Triantaphyllou 2007). Under such circumstances, historical grievances and unresolved conflicts are likely to spark more violent conflicts. The military balance in the region clearly favours Russia, despite a decline in the quality of its armed forces. Smaller powers, on the other hand, perceive the use of force as a tool to resolve conflicts between and within states. Such a perception is strengthened by the Russian-Georgian war of 2008 as well as the ineffectiveness of international institutions in resolving the regional conflicts. Further interstate conflicts are likely in the region due to the protracted nature of conflicts, assertive Russian foreign policy involving the use of force, the lack of effective assistance from international and transatlantic institutions for conflict resolution and the militarization of some regional actors as reflected in higher defence budgets. Since the end of the Cold War, providing security in the Black Sea region seems more difficult than ever before.

The analysis of the military balance in the region recommends some policy prescriptions to decision-makers. First, military expenditure and activities should be monitored with caution, particularly those of the actors involved in unresolved conflicts. Steady increases in military spending may represent plans to resolve conflicts using force. Also, minor skirmishes at borders in conflict zones should be watched with care and must be ended as quickly as possible. These minor battles may create spillover effects that can turn into larger armed conflicts. More specifically, the armaments by Azerbaijan, Armenia, Georgia and its breakaway regions and border skirmishes in these areas must be controlled. Second, Russia's foreign and military 
policies must be carefully considered regarding security issues and unresolved conflicts in the region. Russia has stake in every unresolved conflict in the region and appears to defend these interests more ambitiously than a decade ago. Policies that will antagonize Russia are more likely to fail than succeed. Plans for NATO expansion to Ukraine and Georgia need to be downgraded. The most efficient way to deal with Russia may be through joint policy-making in international organisations such as the BSEC and the Organization for Security and Co-operation in Europe (OSCE). Third, international organizations must be provided with more resources to help resolve regional conflicts and prevent militarization. To that aim, national governments that have interests in the region should choose to support multilateral policy-making through intergovernmental organizations. For example, the support for the OSCE Minsk Group from France, Russia and the USA is an example of such efforts. Finally, further regionalization efforts should be developed in order to create and maintain a culture of cooperation in the region. Economic and trade policy cooperation at the BSEC platform should be advanced to create multilayered interdependencies among regional actors. Such dependencies will naturally help to resolve conflicts over the long-run and advance security sector cooperation in the Black Sea region.

\section{Acknowledgement}

The author would like to thank Mustafa Aydın and Dimitrios Triantaphyllou for their valuable comments, and Ömer Fazlıoğlu for his research assistance.

\section{Notes}

1. Operation Active Endeavour was initiated in October 2001 as NATO's immediate response to the 9/11 attacks. Currently, from the Eastern Mediterranean to the Strait of Gibraltar, NATO ships are patrolling, monitoring shipping and providing escorts to non-military vessels against terrorist activities. More than 75,000 ships were monitored and 100 boarded in the operation so far.

2. Turkey sees Black Sea Harmony in affiliation with the NATO's Active Endeavour and provides the NATO headquarters in Naples with the information gathered from the initiative.

3. Quantitative comparisons are useful; however, readers should be aware of its limitations too. First, data from different sources often conflict with each other. Therefore, SIPRI and Military Balance data-sets that are generally considered objective sources are used. Second, many aspects of military balance such as force quality cannot be qualified. Third, due to space constraints, this analysis only focuses on interstate military balance. Non-state actors and their influences cannot be included. Fourth, more detailed analyses of military spending lead to safer conclusions (Cordesman 2004). For example, breaking down total spending and analysing the specifics of expenditure provide a better analysis. Yet, that should be a part of another study since the range of topics covered in this article is too large.

4. Power is a central concept in the analysis of peace and conflict. The variable, Composite Index of National Capability (CINC), used here is an index variable that operationalises power and is based on the annual values for total population, urban population, iron and steel production, energy consumption, military personnel and military expenditure of a given country.

5. Such a comparison involves only conventional forces and excludes Russia's nuclear capabilities and its unique nuclear power status in the Black Sea.

\section{Notes on contributor}

Özgür Özdamar is an Assistant Professor at the Department of International Relations of Bilkent University. 


\section{References}

Asmus, R., ed. 2006. Next steps in forging a Euroatlantic strategy for the wider Black Sea. Washington, DC: German Marshall Fund of the United States.

Aydin, M. 2004. Europe's next shore: Black Sea after the enlargement (ISS Occasional Paper 53). Paris: EU Institute for Security Studies.

Aydin, M. 2005. Europe's new region: Black Sea in wider Europe-neighbourhood. Journal of Southeast European and Black Sea Studies 5, no. 2: 257-83.

BBC News. 2008. Day-by-day: Georgia-Russia crisis. August 21. http://news.bbc.co.uk/2/hi/ europe/7551576.stm.

Civil Georgia. 2008. Abkhazia, S. Ossetia formally declared occupied territory. August 28. http://www.civil.ge/eng/article.php?id=19330.

Cordesman, A. 2004. The military balance in the Middle East. Westport, CT: Praeger.

Hacioğlu, N. 2009. Bu son, vururuz. Hürriyet, November 22. http://www.hurriyet.com.tr/ dunya/13011166.asp?top=1.

International Crisis Group. 2008a. Georgia and Russia: Clashing over Abkhazia. Europe Report 193, June 5.

International Crisis Group. 2008b. Russia vs Georgia: The fallout. Europe Report 195, August 22.

International Institute for Strategic Studies. 2009. The military balance 2009. New York and London: Routledge.

Karadeniz, B. 2007. Security and stability architecture in the Black Sea. Perceptions (Winter): 95-117.

Nichol, J. 2008. Russia-Georgia conflict in South Ossetia: Context and implications for US interests. CRS Reports RL34618, October 24.

Olson, A. 2009. Azerbaijan military threat to Armenia. Telegraph, November 22. http://www. telegraph.co.uk/news/worldnews/middleeast/azerbaijan/6631572/Azerbaijan-militarythreat-to-Armenia.html.

Putin, V. 2007. Speech at the 43rd Munich Security Conference. http://www.securityconference. de/archive/konferenzen/rede.php?menu_2007=\&menu_konferenzen=\&sprache=en\&id= $179 \&$.

Simon, J. 2006. Black Sea regional security cooperation: Building bridges and barriers. Harvard University, Black Sea Security Program, January. http://www.harvard-bssp.org/ bssp/news.

Singer, J.D., S. Bremer, and J. Stuckey. 1972. Capability distribution, uncertainty, and major power war, 1820-1965. In Peace, war, and numbers, ed. B. Russett, 19-48. Beverly Hills, CA: Sage.

SIPRI (Stockholm International Peace Research Institute). 2009. The SIPRI Military Expenditure Database consistent time series on the military spending of 171 countries since 1988. http://www.sipri.org/research/armaments/milex/research/armaments/milex/ milex_database.

Socor, V. 2005. Kremlin redefining policy in post-Soviet space. Eurasia Daily Monitor 2, no. 27.

Triantaphyllou, D. 2007. Energy security and common foreign and security policy (CFSP): The wider Black Sea area context. Journal of Southeast European and Black Sea Studies 7, no. 2: 289-303.

Triantaphyllou, D. 2008. The wider Black Sea area and its challenges. Dimitrios' World blog, May 12. http://dimitriosworld.blogspot.com/2008/05/wider-black-sea-area-and-itschallenges.html.

Tsygankov, A. 2006. New challenges for Putin's foreign policy. Orbis: A Journal of World Affairs 50, no. 1: 153-65.

Waltz, K. 2000. Structural realism after the Cold War. International Security 25, no. 1: 5-41. 